\section{Side-effect of Phenindione}

SIR,- - I would like to bring to the attention of other physicians a brownish-yellow discoloration of the fingernails which became evident in one of my patients who was treated with long-term anticoagulants for coronary disease. This patient was started on phenindione in April, 1962, and put on a long-term maintenance dose on May 2, 1962, but in August, 1962, he noted that the peripheral third of every finger-nail in the hands had become brownish-yellow in colour, and this has persisted up to the present date. $\mathrm{He}$ is still on a maintenance therapy of "dindevan" (phenindione) $75 \mathrm{mg}$. daily. I would be very interested to learn if other physicians have noted this unusual side-effect of phenindione.I am, etc.,

$$
\text { St. Helen Hospital, }
$$

I. McLean Baird. results afford no proof that the hypotensive action of methyldopa is due to its suppressing noradrenaline synthesis. They may equally be due to interference with the release or the storage of noradrenaline.-We are, etc.,
Group Laboratory,
Warwick Hospital,
Warwick.
S. R. F. WhitTAKer.
R. ROBINSON.
A. W. Stott.

REFERENCES

${ }^{1}$ Stott, A. W., Robinson, R., and Smith, P., Lancet, 1963, 1,

2 Pisano, J. J., Clin. chim. Acta, 1960, 5, 406.

\section{Drugs for Depression}

SIR,-May I be allowed to correct Dr. W. Sargant on one or two points in his otherwise helpful letter on drugs for depression (February 9, p. 401)? He appears to be under the impression that psychiatrists in psychiatric hospitals only deal with severe cases. $\mathrm{He}$ is, of course, quite wrong. The majority of the mental hospitals in the country serve not only busy out-patient clinics but also run their own acute in-patient units doing work exactly comparable to the work of psychiatric units in general hospitals, and therefore their experience is of the same type of case referred to by Dr. Sargant. Like him they have found great benefit from the use of antidepressant drugs, which do indeed enable the general practitioner to treat many cases of depression. Nevertheless it is necessary to emphasize that treatment of depression, and in particular the problem of estimating suicidal risk, should not be considered a simple matter of tablets.-I am, etc.,

The Towers Hospital,

H. B. KIDD.

\title{
Methyldopa and Hypertension
}

SIR,-Dr. Philip Lauwers and his colleagues (February 2, p. 295) were unable to find a reduction in the excretion of total metanephrines in hypertensive patients treated with methyldopa. They comment, however, that since methyldopa can be metabolized to $\alpha$-methyl noradrenaline, which in turn undergoes 3-O-methylation, they could not interpret their results until they were able to separate the $\alpha$-methyl from the physiological metanephrines.

We have recently shown ${ }^{1}$ that patients treated with methyldopa may excrete significantly raised amounts of total metadrenalines. This is due largely to the presence of a 3-O-methyl catechol tentatively identified from its chromatographic properties as $\alpha$-methyl normetanephrine.

We have now separated this substance chromatographically from normetanephrine and estimated the normetanephrine spectrophotometrically after its oxidation to vanillin ${ }^{2}$ (see Table).

It can be seen that in three of the five patients there was a significant fall in both the normetanephrine output and the blood-pressure. Nevertheless, these preliminary

\begin{tabular}{|c|c|c|c|c|}
\hline \multirow[b]{2}{*}{ Patient } & \multicolumn{2}{|c|}{ Before " Aldomet" } & \multicolumn{2}{|c|}{ After " Aldomet" } \\
\hline & $\begin{array}{c}\text { Normetanephrine } \\
\text { Excretion } \\
\text { (mg./day) }\end{array}$ & $\begin{array}{c}\text { Blood } \\
\text { Pressure } \\
\text { (mm. Hg) }\end{array}$ & $\begin{array}{l}\text { Normetanephrine } \\
\text { Excretion } \\
\text { (mg. iday) }\end{array}$ & $\begin{array}{c}\text { Blood } \\
\text { Pressure } \\
\text { (mm. Hg) }\end{array}$ \\
\hline $\begin{array}{l}1 \\
2 \\
3 \\
4 \\
5\end{array}$ & $\begin{array}{l}0.255 \\
0.28 \\
0.5 \\
0.523 \\
0.346\end{array}$ & $\begin{array}{l:l}230 / 130 \\
230 & 140 \\
220 / 130 \\
180 & 120 \\
220 / 110\end{array}$ & $\begin{array}{l}0.184 \\
0.163 \\
0.25 \\
0.723 \\
0.384\end{array}$ & $\begin{array}{l}160 / 100 \\
165 / 110 \\
190 / 110 \\
150 / 110 \\
220 / 130\end{array}$ \\
\hline
\end{tabular}

All patients received $500 \mathrm{mg}$. methyldopa b.d. before the second specimen was collected.

\section{Danger Corner}

SIR,-In the section entitled "Danger Corner" (February 16, p. 454) there is a description of a case report by Gilbert. ${ }^{1}$

In the original article, the author describes how the patient received courses of erythromycin stearate and erythromycin estolate without symptoms. The latter course almost certainly sensitized the patient, since a challenge dose of erythromycin estolate on two occasions resulted in symptoms and signs of hepatitis within twelve hours of ingestion. However, the author goes on to state, "A final challenge of $250 \mathrm{mg}$. of erythromycin stearate resulted in no clinical or laboratory evidence of hepatitis."-I am, etc.,

$$
\begin{aligned}
& \begin{array}{c}
\text { Abbott Laboratories Ltd., } \\
\text { Queenborough, Kent. } \\
\text { Reference }
\end{array} \\
& \text { 'Gilbert, F. I., J. Amer. med. Ass., 1962, 182, } 1040 .
\end{aligned}
$$

\section{School Medical Examinations}

SIR,-It is quite extraordinary that from time to time we should get violent protests against the apparent infringement of human liberties and freedom as a result of powers conferred on our own colleagues in the Public Health and School Health Services by Acts of Parliament. Your correspondent Dr. R. G. Newton (January 5 , p. 57) must be a comparatively young man, and one wonders therefore why he did not learn in his medical school a little bit more about the Public Health and Preventive Services in Britain.

Would he take the same objection to some of the provisions of the Public Health Acts which safeguard 